\title{
Relative weight and length of digestive tract and intestinal histomorphometric measurements of slow- growing broilers of different genotypes
}

\author{
Peso relativo e comprimento do trato digestório e \\ medidas histomorfométricas intestinais de frangos de \\ corte de crescimento lento de diferentes genótipos
}

\author{
Saullo Diogo Assis ${ }^{1 *}$; Nadja Susana Mogyca Leandro' ${ }^{2 ;}$ Emmanuel Arnhold ${ }^{2}$; \\ Marcos Barcellos Café2; Fabyola Barros de Carvalho ${ }^{2}$; José Henrique Stringhini2.; \\ Raphael Rodrigues dos Santos ${ }^{3}$.
}

\section{Highlights}

Evaluation of the growth of digestive organs in broilers.

Development of slow-growing broiler strains.

Evaluation of intestinal villus growth in broilers in the starter phase.

\begin{abstract}
An experiment was conducted to investigate the development of the digestive system in slow-growing broilers of different strains. The experiment involved a total of 544 one-day-old chicks, 136 of each of four genotypes, namely, Label Rouge Pesadão, Label Rouge Pescoço Pelado, Carijó and Carijó Pescoço Pelado. The birds were distributed in a completely randomized design with four treatments (genotypes) and eight replicates of 17 animals each. Live weight, digestive tract development and intestinal histomorphometric measurements were evaluated at different ages. Significant differences $(p<0.05)$ were observed between the strains for live weight, relative weight and length of digestive tract organs and intestinal histomorphometric measurements at one, seven and 28 days of age. The Carijó strain showed greater weight and development of digestive organs than the Carijó Pescoço Pelado strain. There was a difference $(p<0.05)$ for histomorphometric measurements of the small intestine between the strains at the evaluated ages. The Carijó Pescoço Pelado and Label Rouge Pescoço Pelado strains showed higher villi and higher villus:crypt ratios in the duodenum, jejunum and ileum. The slow-growing strains differ in performance regarding the relative weights and lengths

1 Prof. Dr., Departamento de Ensino, Instituto Federal de Educação, Ciência e Tecnologia de Mato Grosso, IFMT, Campus São Vicente, Cuiabá, MT, Brasil. E-mail: saullo.assis@gmail.com

2 Profs., Drs., Escola de Veterinária e Zootecnia, Universidade Federal de Goiás, UFG, Goiânia, GO, Brasil. E-mail: nmogyca@ gmail.com; emmanuelarnhold@yahoo.com.br; mcafe@gmail.com; fabyolab@hotmail.com; henrique@ufg.br

${ }^{3}$ Discente do Curso de Mestrado do Programa de Pós-Graduação em Zootecnia, UFG, Goiânia, GO, Brasil. E-mail: rafarrds@gmail.com

* Author for correspondence
\end{abstract}

Received: Apr. 24, 2020 - Approved: Sept. 11, 2020 
of digestive tract organs and intestinal histomorphometric measurements.

Key words: Breeding. Digestion. Genetics. Physiology.

\section{Resumo}

Um experimento foi realizado com o objetivo de avaliar o desenvolvimento do sistema digestório em frangos de corte de crescimento lento de diferentes linhagens. Foram utilizados 544 pintos com um dia de idade, sendo 136 de cada genótipo sendo: Label Rouge Pesadão, Label Rouge Pescoço Pelado, Carijó e Carijó Pescoço Pelado. Distribuídos em um delineamento inteiramente casualizado com quatro tratamentos (genótipo) e oito repetições de 17 animais cada. As variáveis estudadas foram peso vivo, desenvolvimento do trato digestório e medidas histomorfométricas intestinal em diferentes idades. Houve diferença $(p<0,05)$ entre as linhagens no peso vivo, peso relativo e comprimento dos órgãos do trato digestório e medidas histomorfométricas intestinal com um, sete e 28 dias de idade. A linhagem Carijó apresentou maior peso e desenvolvimento de órgãos digestórios comparada a linhagem Carijó Pescoço Pelado. Houve diferença ( $p$ $<0,05)$ para medidas histomorfométricas do intestino delgado entre as linhagens nas idades avaliadas. As linhagens Carijó Pescoço Pelado e Label Rouge Pescoço Pelado apresentaram maior altura de vilo e relação vilo:cripta do duodeno, jejuno e íleo. As linhagens de crescimento lento apresentam diferenças entre si no desempenho peso relativo e comprimento de órgãos do trato digestório e nas medidas histomorfometricas do intestino.

Palavras-chave: Digestão. Fisiologia. Genética. Melhoramento.

\section{Introduction}

The digestive tract of birds is anatomically complete in the final period of the incubation process. However, its functional, digestive and absorptive capacities are still immature when compared with those of older birds. From the 17th day of incubation to the seventh day after birth, birds undergo morphological differentiations in the anatomy of their gastrointestinal tract. Most importantly, there is an increase in the amount of enterocytes-epithelial cells with nutrient absorption function-as well as in intestinal size (Santos, Corção, Kessler, Laranjeira, \& Lima, 2012).

The small intestine of birds increases in weight at a faster rate than the body and essential organs such as the heart and lungs.
Other organs of the digestive tract, such as the gizzard, also do not develop in proportion to the body (Uni, Noy, \& Sklan, 1999). The small intestine has a four-fold greater allometric growth than the entire bird carcass. During the first 27 days of life, goblet cells, which occur in the crypts and intestinal villi, are of fundamental importance for the proper development and preservation of the digestive system (Rocha, Barros, \& Evencio, 2016).

Due to crossing and selective breeding, birds can undergo anatomical variations, especially in the digestive tract (Sousa et al., 2015). Santos et al. (2015) evaluated the relative weight and length of digestive organs and intestinal mucosa morphometry in the broiler strains Isa Label (slow-growing) and Cobb (fast-growing). The authors described that the slow-growing birds had higher relative 
weights of digestive organs, except for the liver and small intestine at seven and 42 days of age, respectively. The Cobb strain showed higher villi in the jejunum and ileum at seven days and in the duodenum at 42 days of age. The researchers concluded that the Isa Label and Cobb strains have peculiarities regarding the development of their digestive system organs.

Genetics directly influences not only production performance, but also digestive tract development (Mendonça et al., 2008). Slow-growing broiler strains have their own genetic traits, which are provided by breeding and which influence their physiological development. Understanding how the digestive tract develops in slow-growing strains is important for establishing the most appropriate nutritional and management plans for each strain in order to reduce costs and serve a more specific consumer market.

In view of the above-described scenario, an experiment was conducted to examine the development of the digestive system in slow-growing broilers of different strains (Label Rouge Pesadão, Label Rouge Pescoço Pelado, Carijó and Carijó Pescoço Pelado) at the ages of one, seven and 28 days.

\section{Material and Methods}

The experiment was carried out in the experimental poultry section of the School of
Veterinary and Animal Science at the Federal University of Goiás, located in Goiânia-GO, Brazil. The research project was approved by the Animal Research Ethics Committee (approval no. 068/16).

A total of 544 one-day-old chicks were used in a completely randomized design with four treatments (strains) and eight replicates of 17 birds. The evaluated strains were Label Rouge Pesadão, Label Rouge Pescoço Pelado, Carijó and Carijó Pescoço Pelado. Each strain was weighed and randomly distributed into the eight replicates according to the average weight of the strain.

Birds were raised in a conventional masonry shed and housed in galvanized-steel battery cages (dimensions: $0.90 \times 0.60 \times 0.40$ $\mathrm{m})$ with five floors, at the density of 17 birds/ cage. The cages were equipped with a drinking trough and a linear feed trough. Heating was provided by gas brooder heaters in the phase from one to 28 days.

Water and feed were provided ad libitum throughout the experimental period, with the feeders being refilled twice daily to avoid wastage. The experimental diets were in mash form, maize- and soybean meal-based and formulated to meet the nutritional requirements for the pre-starter ( 1 to 7 days) and starter ( 8 to 28 days) phases of normal-growing broilers (Table 1) according to Rostagno et al. (2011). All diets were free of growth enhancers and anticoccidial agents. 
Table 1

Percentage composition and calculated nutritional values of the basal diets

\begin{tabular}{lcc}
\hline \multirow{2}{*}{ Ingredient } & \multicolumn{2}{c}{ Age (days) } \\
\cline { 2 - 3 } Ground maize & 1 to 7 & 8 to 28 \\
\hline Soybean meal 45\% & 57.55 & 62.98 \\
\hline Dicalcium phosphate & 37.07 & 32.39 \\
\hline Soybeans oil & 1.91 & 1.46 \\
\hline Calcitic limestone & 1.28 & 1.10 \\
\hline Common salt & 0.89 & 0.96 \\
\hline DL-methionine 99\% & 0.50 & 0.46 \\
\hline L-lysine HCl 98\% & 0.35 & 0.27 \\
\hline Mineral-vitamin supplement ${ }^{1}$ & 0.30 & 0.23 \\
\hline Total (\%) & 0.10 & 0.10 \\
\hline Calculated composition & 100 & 100 \\
\hline Crude protein (\%) & & 20.000 \\
\hline Metabolizable energy (kcal/kg) & 21.800 & 2,980 \\
\hline Calcium (\%) & 2,925 & 0.827 \\
\hline Available phosphorus (\%) & 0.920 & 0.381 \\
\hline Digestible lysine (\%) & 0.470 & 1.135 \\
\hline Digestible methionine + cystine (\%) & 1.297 & 0.818 \\
\hline Sodium (\%) & 0.934 & 0.205 \\
\hline
\end{tabular}

1 Vitamin-mineral supplement: provides per kilogram of product: Folic acid 1,600.00 mg, Pantothenic acid $24.96 \mathrm{~g}$, Biotin 80 mg, Butylated hydroxytoluene 100 mg, Niacin 67.20 g, Selenium 600 mg, Vitamin A 13,4440,000 IU, Vitamin B1 500 mg, Vitamin B12 9,200 mcg, Vitamin B2 9,600 mg, Vitamin B6 4,992 mg, Vitamin D3 3,200,000 IU, Vitamin E 21,000 IU, Vitamin K3 2,880 mg, Copper $15 \mathrm{~g}$, Iron $90 \mathrm{~g}$, lodine 1,500 mg, Manganese $150 \mathrm{~g}$, Zinc140 g.

The studied variables were live weight, digestive tract development and intestinal histomorphometric measurements. At one, seven and 28 days of age, one bird (per replicate) with the average weight of the plot was sacrificed by displacing the craniocervical junction to perform necropsy and collect organs from the digestive system to assess intestinal development.

Allometric assessments were performed by weighing $(\mathrm{g})$ the yolk sac (when present), pancreas, liver without gallbladder and proventriculus + gizzard on an analytical scale with $0.001-g$ precision. The intestinal segments of duodenum, jejunum, ileum, colon-rectum + ceca were also measured $(\mathrm{cm})$ separately, using a measuring tape.

The weights of the birds and each organ were used to calculate the relative weight of the organs (\%), by applying the following formula: Relative organ weight = (Organ weight/Live weight) $\times 100$. For the morphometric analysis of the intestinal mucosa, samples of approximately $4 \mathrm{~cm}$ were taken from the following segments of the small intestine: duodenum: from the pylorus to the 
distal portion of the duodenal loop; jejunum: from the distal portion of the duodenal loop to Meckel's diverticulum; ileum: portion anterior to the caecum. The samples were opened lengthwise by the mesenteric border, deposited on Styrofoam plates and fixed in a $10 \%$ buffered formaldehyde solution for $24 \mathrm{~h}$. After this period, the formaldehyde solution was removed and replaced with $70 \%$ alcohol until the slides were prepared.

In the preparation of the slides, the intestinal sections were dehydrated in an increasing series of ethanol, cleared in xylol and embedded in paraffin. After this procedure, 6 - $\mu$ m-thick multi-serial sections were made and six sections from each segment were chosen, placed on a glass slide, stained in hematoxylin-eosin (HE) and covered with a glass coverslip. The HE- stained fragments had the morphometric indices determined using AxioVision 3.0 software. The images of the digitalized slides were uploaded from the bright-field optical microscope (Carl Zeiss model JENAVAL) to the computer using an analog video camera and a capture card.

The images were obtained under $5 x$ magnification, using the LeicaDM 4000Boptical microscope attached to a microcomputer. Subsequently, the images were analyzed using Image J software, in which ten measurements of villus height $(\mathrm{VH})$ and crypt depth $(\mathrm{CD})$ of each segment were performed, per replicate, totaling 240 measurements per treatment, at each evaluated age.

The evaluated intestinal histomorphometric variables were $\mathrm{VH}$ and $C D$, measured in micrometers $(\mu \mathrm{m})$, and villus height/crypt depth ratio (V:C). Villus height was measured from the basal region coinciding with the upper portion of the crypts up to the apex of the villi. Crypt depth was measured from the basal region of the villi until their delimitation.

Data were subjected to analysis of variance and Tukey's test was applied to compare the means, at a $5 \%$ significance level. Homogeneity of variances (Bartlett's test) and normality of residues (Shapiro-Wilk) were checked. For the analyses, R Core Team [R] (2017) software was used.

\section{Results and Discussion}

Differences were observed $(p<0.05)$ between the strains for body weight and the relative weights of proventriculus + gizzard, liver, jejunum, ileum and large intestine (Table 2 ) at one day of age. With respect to the length of the small-intestine segments, differences ( $p$ $<0.05$ ) were observed for the jejunum, ileum and large intestine. 
Table 2

Relative weight and length of digestive organs of the Carijó, Carijó Pescoço Pelado (Carijó P), Label Rouge Pescoço Pelado (Label P) and Label Rouge Pesadão (Label) strains at one day of age

\begin{tabular}{lcccccc} 
& Carijo & Carijo P & Label P & Label & P-value & CV \% \\
\cline { 2 - 7 } Live weight (g) & $38.35 \mathrm{~b}$ & $38.98 \mathrm{a}$ & $38.95 \mathrm{a}$ & $38.47 \mathrm{~b}$ & 0.001 & 0.80 \\
\hline Yolk sac & \multicolumn{7}{c}{ Relative weight (\%) } \\
Proventriculus + gizzard & 8.53 & 6.30 & 6.34 & 6.47 & 0.975 & 17.24 \\
Pancreas & 0.23 & $0.22 \mathrm{ab}$ & $7.65 \mathrm{c}$ & $8.04 \mathrm{bc}$ & 0.001 & 4.22 \\
Liver & $5.28 \mathrm{a}$ & $3.02 \mathrm{~b}$ & $2.69 \mathrm{~b}$ & $2.85 \mathrm{~b}$ & 0.001 & 11.23 \\
Duodenum & 1.21 & 1.26 & 1.24 & 1.23 & 0.941 & 10.87 \\
Jejunum & $1.31 \mathrm{ab}$ & $1.15 \mathrm{c}$ & $1.22 \mathrm{bc}$ & $1.41 \mathrm{a}$ & 0.001 & 8.69 \\
lleum & $0.87 \mathrm{a}$ & $0.72 \mathrm{~b}$ & $0.72 \mathrm{~b}$ & $0.71 \mathrm{~b}$ & 0.001 & 8.43 \\
Large intestine & $1.44 \mathrm{a}$ & $1.06 \mathrm{~b}$ & $1.07 \mathrm{~b}$ & $1.52 \mathrm{a}$ & 0.001 & 13.90 \\
& & Length (cm) & & & \\
Duodenum & 10.25 & 9.80 & 9.72 & 10.31 & 0.138 & 5.79 \\
Jejunum & $16.82 \mathrm{a}$ & $14.51 \mathrm{~b}$ & $16.11 \mathrm{ab}$ & $15.60 \mathrm{ab}$ & 0.029 & 8.96 \\
Ileum & $11.43 \mathrm{ab}$ & $12.45 \mathrm{a}$ & $12.06 \mathrm{a}$ & $10.25 \mathrm{~b}$ & 0.008 & 10.55 \\
Large intestine & $6.87 \mathrm{a}$ & $6.71 \mathrm{ab}$ & $6.06 \mathrm{c}$ & $6.28 \mathrm{bc}$ & 0.001 & 5.97
\end{tabular}

*Means followed by different letters in the same row differ by Tukey's test $(p<0.05)$. CV = coefficient of variation. P-value = significance probability.

The Carijó strain showed the highest relative weights of proventriculus + gizzard, liver, jejunum, ileum and large intestine as well as the longest jejunum, ileum and large intestine, at one day of age. According to Sousa et al. (2015), some aspects related to the physiology of the digestive tract elucidate the greater development of certain organs, which occurs due to an increase in other organs with which they have a physiological relationship.

A higher percentage of digestive organs may result in better use of the feed, since the size of the gastrointestinal tract as well as its efficiency in the breakdown and absorption of nutrients will positively affect nutrient utilization. Verdal et al. (2010) evaluated the morphology of the gastrointestinal tract of two broiler strains selected for high or low energy use of wheat-based diets. The authors found that the birds of the strain selected for high energy use had heavier gizzards and proventriculi than those with low energy use efficiency.

The association of the data on the relative digestive organ weights of the strains at one day of age was analyzed using the canonical variables plot (Figure 1). The relative weights of proventriculus + gizzard, liver and ileum and the length of the large intestine were found to be positively associated with each other and were higher for the Carijó strain. A higher percentage of organs responsible for nutrient digestion and metabolism is favorable to an improved utilization of feed, that is, these 
birds tend to perform better when compared with other birds with a lower percentage of digestive tract organs.

The Carijó and Label Pescoço Pelado strains showed a negative correlation with live weight. The relative weights of the jejunum and large intestine and the lengths of jejunum and duodenum were positively correlated and higher for the Label strain (Figure 1). The Carijó Pescoço Pelado and Label Pescoço Pelado strains showed higher values for the relative weights of yolk sac and duodenum; live weight; and ileum length. A positive correlation was detected between the relative weights of the yolk sac and duodenum, live weight and ileum length (Figure 1).

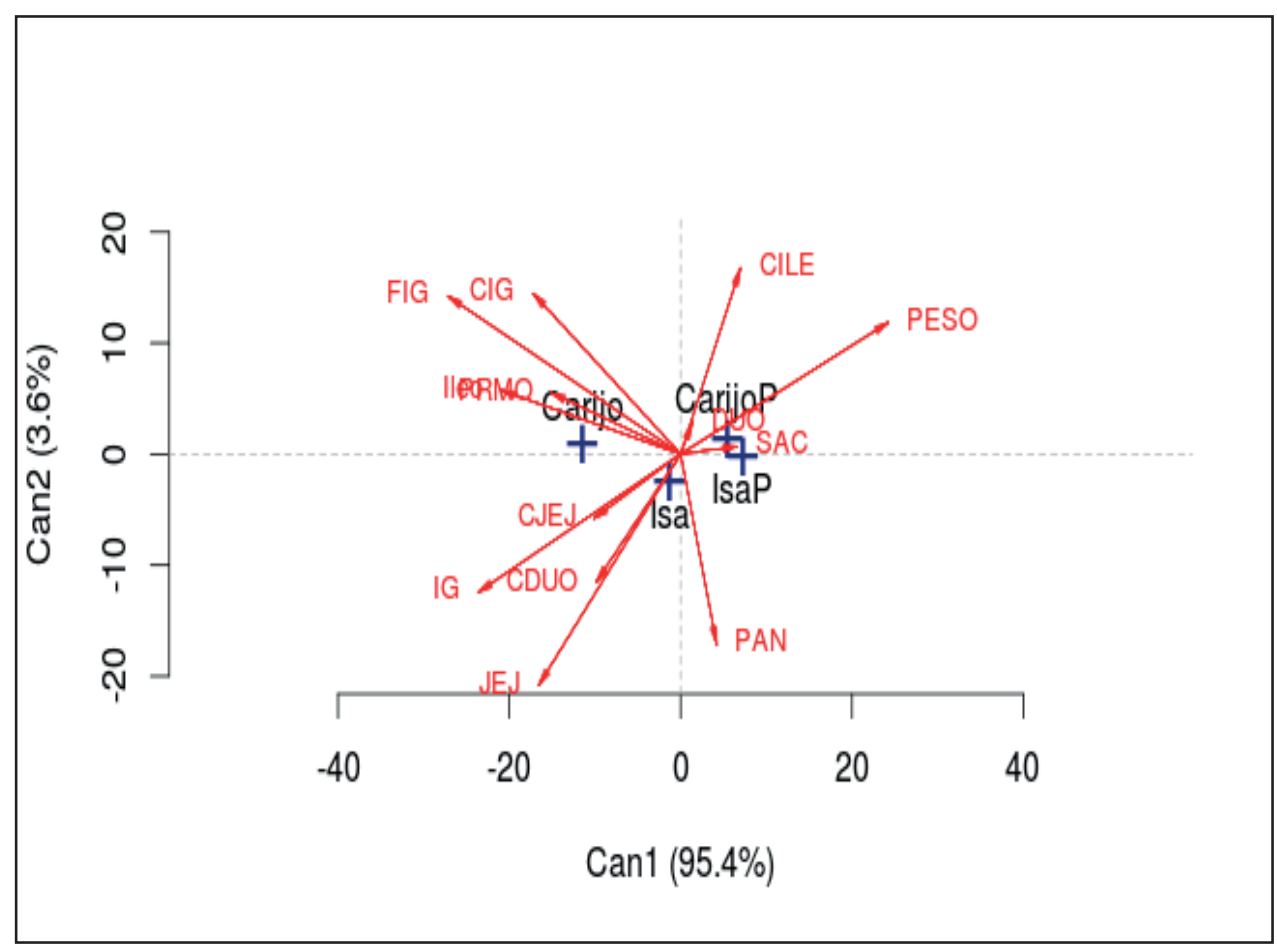

Figure 1. Boxplot of live weight (WEIGHT) and relative weight (yolk sac SAC, proventriculus + gizzard - PVG, pancreas - PAN, liver - LIV, duodenum - DUO, jejunum - JEJ, ileum - ILE and large intestine - LI) and length (duodenum - DUOL, jejunum - JEJL, ileum - ILEL and large intestine - LIL) of organs in the Label Rouge Pesadão (Isa), Label Rouge Pescoço Pelado (IsaP), Carijó and Carijó Pescoço Pelado (CarijóP) strains at one day of age. 
Differences were detected $(p<0.05)$ between the studied strains for body weight; relative weight of the large intestine; and lengths of the duodenum, jejunum and large intestine, at seven days of age (Table 3). The Carijó strain showed the highest values for body weight; relative large intestine weight; and lengths of duodenum, jejunum and large intestine, at seven days of age.

Sousa et al. (2015) investigated the correlation between live weight and duodenal and jejunal development in fastgrowing broilers and found a high correlation between live weight and duodenal length. The authors described that increased weight gain is only achieved through an improved nutrient metabolization process, with greater absorption. Accordingly, the duodenum tends to increase in size to better exercise its absorption function.

In this study, the Carijó strain showed a higher relative weight and a longer large intestine than the other studied strains. According to Sousa et al. (2015), the ceca are highly correlated with the duodenum; in other words, greater duodenal development provides greater development to the large intestine, which is composed mainly of the cecum.

\section{Table 3}

Relative weight and length of digestive organs of the Carijó, Carijó Pescoço Pelado (Carijó P), Label Rouge Pescoço Pelado (Label P) and Label Rouge Pesadão (Label) strains at seven days of age

\begin{tabular}{lcccccc} 
& Carijo & Carijo P & Label P & Label & P-value & CV (\%) \\
\cline { 2 - 7 } Body weight (g) & $137 \mathrm{a}$ & $111 \mathrm{c}$ & $128 \mathrm{~b}$ & $129 \mathrm{~b}$ & 0.001 & 3.47 \\
\hline Yolk sac & 0.04 & 0.02 & 0.05 & 0.03 & 0.871 & 151.91 \\
Proventriculus + gizzard & 5.96 & 6.07 & 5.88 & 5.49 & 0.106 & 7.34 \\
Pancreas & 0.55 & 0.51 & 0.50 & 0.51 & 0.163 & 9.19 \\
Liver & 3.94 & 3.77 & 3.70 & 4.02 & 0.439 & 10.70 \\
Duodenum & 2.12 & 1.90 & 2.19 & 2.15 & 0.249 & 13.65 \\
Jejunum & 2.78 & 2.83 & 2.82 & 2.81 & 0.993 & 13.66 \\
lleum & 1.93 & 1.61 & 1.71 & 1.98 & 0.091 & 17.23 \\
Large intestine & $1.74 \mathrm{ab}$ & $1.48 \mathrm{~b}$ & $1.39 \mathrm{~b}$ & $2.03 \mathrm{a}$ & 0.003 & 19.32 \\
& \multicolumn{7}{c}{ Length (cm) } & & & \\
Duodenum & $18.20 \mathrm{ab}$ & $16.31 \mathrm{~b}$ & $19.66 \mathrm{a}$ & $17.07 \mathrm{ab}$ & 0.055 & 12.71 \\
Jejunum & $36.07 \mathrm{a}$ & $31.93 \mathrm{~b}$ & $31.85 \mathrm{~b}$ & $33.88 \mathrm{ab}$ & 0.017 & 7.97 \\
lleum & 28.25 & 25.50 & 24.57 & 26.62 & 0.275 & 13.79 \\
Large intestine & $11.42 \mathrm{a}$ & $9.71 \mathrm{bc}$ & $9.31 \mathrm{c}$ & $10.81 \mathrm{ab}$ & 0.001 & 9.82
\end{tabular}

*Means followed by different letters in the same row differ by Tukey's test $(p<0.05)$. CV = coefficient of variation. P-value = significance probability.

At seven days of age, an overlap was observed between the relative weight of the digestive tract organs and the studied strains (Figure 2). 


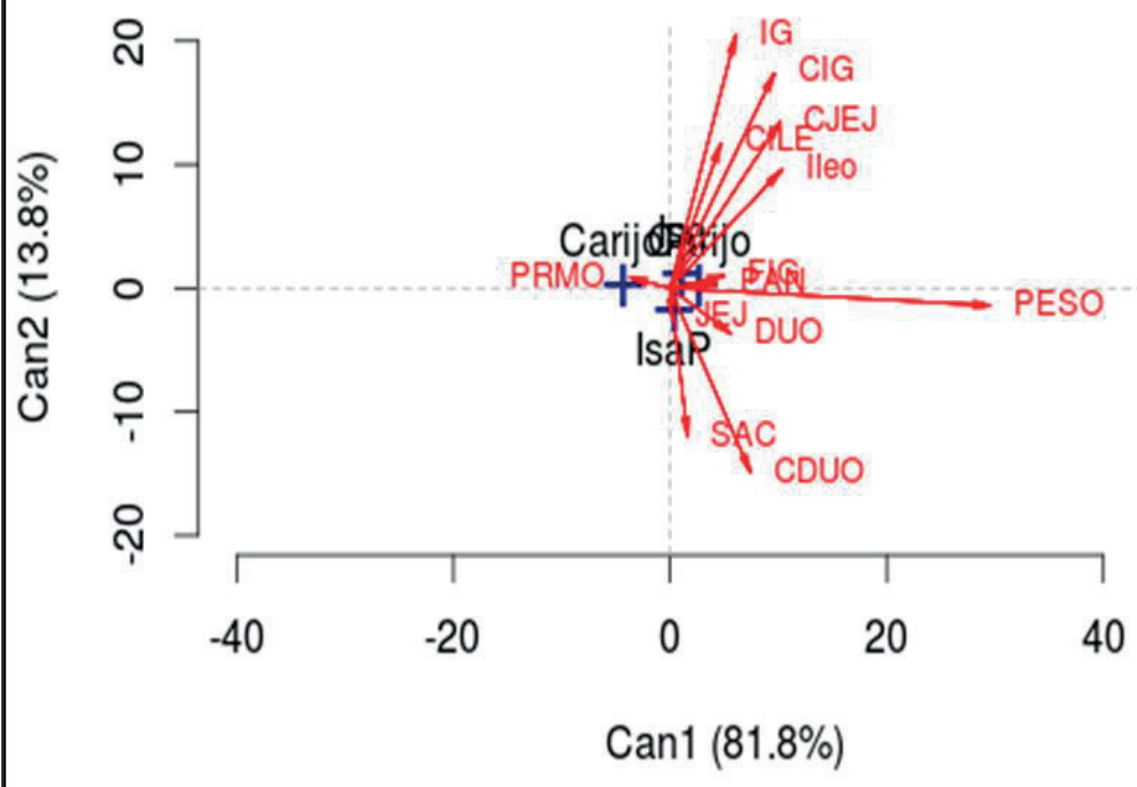

Figure 2. Boxplot of live weight (WEIGHT) and relative weight (yolk sac - SAC, proventriculus + gizzard - PVG, pancreas - PAN, liver - LIV, duodenum - DUO, jejunum - JEJ, ileum - ILE and large intestine - LI) and length (duodenum - DUOL, jejunum - JEJL, ileum - ILEL and large intestine - LIL) of organs in the Label Rouge Pesadão (Isa), Label Rouge Pescoço Pelado (IsaP), Carijó and Carijó Pescoço Pelado (CarijóP) strains at seven days of age.

The Carijó strain showed a higher relative weight of proventriculus + gizzard and a negative correlation with live weight (Figure 2). The proventriculus + gizzard, along with the other organs of the digestive system, grow considerably after hatching (Reis et al., 2015). This increase is not accompanied by the bird's weight, since the proventriculus + gizzard index is relative to the live weight of the bird.

At seven days of age, the relative weights of liver and pancreas were positively correlated with live weight (Figure 2). Cançado and Baião (2002) described that most part of liver growth occurs during the first week, and the growth rate of the pancreas decreases linearly as the bird ages. As can be seen in Figure 3 , there was a negative correlation between bird weight and the relative weight of the pancreas at 28 days of age. However, the relative liver weight showed to be positively correlated with bird live weight.

The Carijó Pescoço Pelado strain showed the highest relative weights of proventriculus + gizzard and duodenum. However, live weight was negatively correlated with the strain and with the weight of the 
proventriculus + gizzard. According to Zocche, Souza and Gewehr (2016), smaller birds have higher proventriculus + gizzard indices and larger digestive organs than heavier chicks.

At 28 days of age, there was a difference $(p<0.05)$ between the strains for body weight; relative weights of proventriculus + gizzard and pancreas; and lengths of duodenum, jejunum, ileum and large intestine (Table 4). The live weights of the Carijó and Label Rouge strains were higher than those of the Label Rouge Pescoço Pelado and Carijó Pescoço Pelado strains.

Table 4

Relative weight and length of digestive organs of the Carijó, Carijó Pescoço Pelado (Carijó P), Label Rouge Pescoço Pelado (Label P) and Label Rouge Pesadão (Label) strains at 28 days of age

\begin{tabular}{lcccccc}
\hline \multirow{2}{*}{ Body weight (g) } & Carijo & Carijo P & Label P & Label & P-value & CV \% \\
\cline { 2 - 7 } & $960 \mathrm{a}$ & $659 \mathrm{c}$ & $854 \mathrm{~b}$ & $943 \mathrm{a}$ & 0.001 & 6.40 \\
\hline Proventriculus + gizzard & $3.08 \mathrm{c}$ & $3.54 \mathrm{ab}$ & $3.73 \mathrm{a}$ & $3.27 \mathrm{bc}$ & 0.001 & 7.50 \\
Pancreas & $0.30 \mathrm{~b}$ & $0.38 \mathrm{a}$ & $0.37 \mathrm{a}$ & $0.28 \mathrm{~b}$ & 0.001 & 11.04 \\
Liver & 2.44 & 2.61 & 2.86 & 2.63 & 0.119 & 12.72 \\
Duodenum & 1.15 & 1.28 & 1.21 & 1.18 & 0.445 & 14.01 \\
Jejunum & 1.90 & 1.78 & 1.93 & 1.72 & 0.079 & 9.68 \\
Ileum & 1.43 & 1.54 & 1.74 & 1.41 & 0.100 & 18.39 \\
Large intestine & 1.27 & 1.18 & 1.12 & 1.06 & 0.316 & 19.05 \\
& $27.83 \mathrm{a}$ & $21.77 \mathrm{~b}$ & $25.45 \mathrm{a}$ & $24.28 \mathrm{ab}$ & 0.001 & 10.26 \\
Duodenum & $54.68 \mathrm{a}$ & $48.50 \mathrm{~b}$ & $53.90 \mathrm{a}$ & $47.01 \mathrm{~b}$ & 0.035 & 11.24 \\
Jejunum & $53.37 \mathrm{ab}$ & $44.00 \mathrm{c}$ & $57.62 \mathrm{a}$ & $47.37 \mathrm{bc}$ & 0.003 & 13.49 \\
Ileum & $22.43 \mathrm{a}$ & $18.27 \mathrm{~b}$ & $20.58 \mathrm{ab}$ & $19.92 \mathrm{ab}$ & 0.001 & 9.32 \\
Large intestine & \multicolumn{7}{c}{ Relive weight (\%) }
\end{tabular}

*Means followed by different letters in the same row differ by Tukey's test $(p<0.05)$. CV = coefficient of variation. P-value = significance probability.

The Carijó Pescoço Pelado and Label Rouge Pescoço Pelado strains showed the highest percentages of relative proventriculus + gizzard and pancreas weights. These higher values are due to the low body weight of these strains. Relative weight is a measurement that represents the percentage of the organ in relation to the bird's body weight. Because these strains had a lower body weight, there was an increase in the relative weight of the organs. The higher relative weight of digestive organs in the chickens can be explained by the smaller size of their carcass. As the Carijó strain showed a higher body weight, the relative weights of internal organs in these birds were consequently compromised.

There was a difference $(p<0.05)$ in the lengths of duodenum, jejunum, ileum and 
large intestine between the studied strains at 28 days of age. The Carijó strain exhibited the longest duodenum and large intestine. The duodenum is the portion responsible mainly for the digestion of the nutrients from the feed. It is the site where the action of pancreatic juice and bile containing its digestive enzymes and emulsifying substances occurs. A greater development of this segment increases the time of action and contact of the bolus with digestive enzymes, thus improving digestive processes and providing a greater content of nutrients to be absorbed.

Small intestine length can be considered an indicator of good intestinal mucosal development. This has a direct impact on intestinal health and nutrient absorption, since a longer intestine means a larger area of exposure of nutrients to absorptive cells (Guerra, 2018). The findings in this study demonstrate that the greater intestinal development of the Carijó strain provided better performance and nutrient use, especially of protein and mineral matter.

The Carijó, Label Rouge and Label Rouge Pescoço Pelado strains showed higher live weights; relative weights of liver and jejunum; and lengths of duodenum, jejunum, ileum and large intestine. There was a positive correlation between the lengths of duodenum, jejunum, ileum and large intestine (Figure 3).

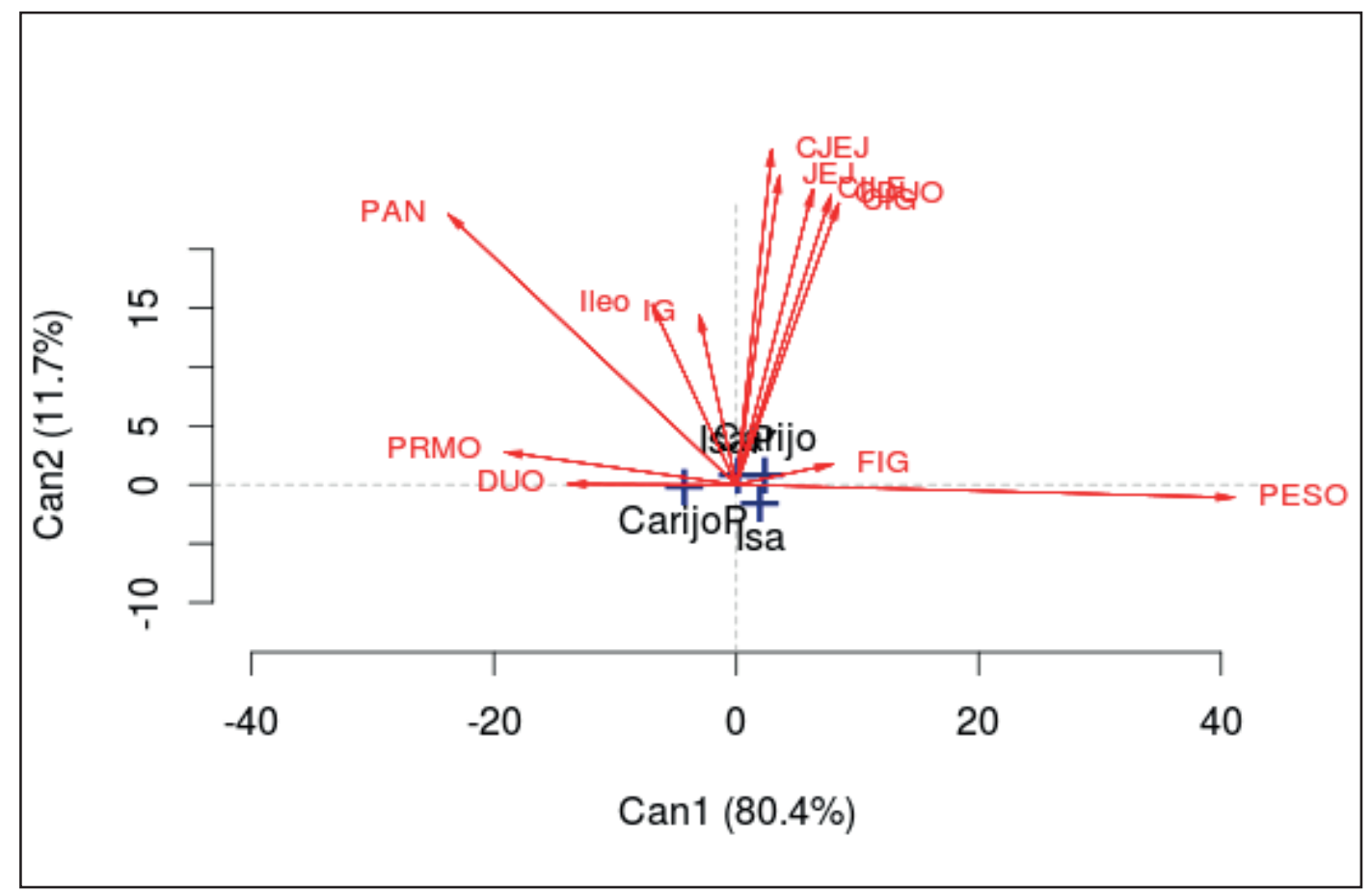

Figure 3. Boxplot of live weight (WEIGHT) and relative weight (yolk sac - SAC, proventriculus + gizzard - PVG, pancreas - PAN, liver - LIV, duodenum - DUO, jejunum - JEJ, ileum - ILE and large intestine - LI) and length (duodenum - DUOL, jejunum - JEJL, ileum - ILEL and large intestine - LIL) of organs in the Label Rouge Pesadão (Isa), Label Rouge Pescoço Pelado (IsaP), Carijó and Carijó Pescoço Pelado (CarijóP) strains at 28 days of age. 
The higher live weight of the Carijó strain at seven and 28 days of age can be attributed to the better development of the digestive tract organs responsible for the gastric digestion of the feed and nutrient metabolization on their first day of life. According to Sousa et al. (2015), animals with higher weight gains require a greater nutrient metabolization process, with greater absorption. As a result, the duodenum tends to increase to better perform its function and increase the time of contact with the absorption surface.

There was a difference $(p<0.05)$ for the histomorphometric measurements of the small intestine at one day of age. At one day of age, the Label Rouge Pescoço Pelado strain showed the longest villi $(\mu \mathrm{m})$ and the highest $\mathrm{V}: \mathrm{C}$ ratio in the duodenum. The Carijó Pescoço Pelado broilers showed the highest villi in the jejunum and ileum (Table 5). There was no difference ( $p$ $>0.05$ ) for $\mathrm{V}: \mathrm{C}$ ratio in the jejunum and ileum between the studied strains. The absorption of digestion products occurs entirely in the small intestine, by two mechanisms: diffusion and active transport. This absorption is facilitated, among other factors, by the villi. The increase in intestinal length; villus height and density; and number of enterocytes and goblet cells results in an increased surface area for digestion and absorption (Oliveira et al., 2012).

\section{Table 5}

Histomorphometric measurements of the small intestine (duodenum, jejunum and ileum) of the Carijó, Carijó Pescoço Pelado (Carijó P), Label Rouge Pescoço Pelado (Label P) and Label Rouge Pesadão (Label) strains at one day of age

\begin{tabular}{|c|c|c|c|c|c|c|}
\hline \multirow{2}{*}{ Variable } & \multicolumn{6}{|c|}{ Strain } \\
\hline & Carijó & Carijó P & Label P & Label & P-value & CV \% \\
\hline \multicolumn{7}{|c|}{ Duodenum $(\mu \mathrm{m})$} \\
\hline Villus height & $492.0 \mathrm{a}$ & $514.6 \mathrm{a}$ & $568.6 \mathrm{a}$ & $281.6 b$ & 0.001 & 20.12 \\
\hline Crypt depth & $57.4 \mathrm{ab}$ & $65.0 \mathrm{a}$ & $48.4 \mathrm{~b}$ & $57.9 \mathrm{ab}$ & 0.008 & 14.63 \\
\hline V:C ratio & $8.2 \mathrm{ab}$ & $8.1 \mathrm{~b}$ & $11.8 \mathrm{a}$ & $4.8 \mathrm{c}$ & 0.001 & 28.61 \\
\hline \multicolumn{7}{|c|}{ Jejunum ( $\mu \mathrm{m})$} \\
\hline Villus height & $270.6 b$ & $365.0 \mathrm{a}$ & $280.5 b$ & $313.5 a b$ & 0.001 & 11.13 \\
\hline Crypt depth & $40.8 b$ & $52.6 \mathrm{a}$ & $47.6 \mathrm{ab}$ & $45.8 \mathrm{ab}$ & 0.039 & 16.03 \\
\hline V:C ratio & 6.3 & 7.1 & 5.7 & 6.9 & 0.157 & 18.51 \\
\hline \multicolumn{7}{|c|}{ Ileum $(\mu \mathrm{m})$} \\
\hline Villus height & $251.8 b$ & $290.4 \mathrm{a}$ & $257.8 \mathrm{ab}$ & $228.9 \mathrm{~b}$ & 0.001 & 10.08 \\
\hline Crypt depth & $60.0 \mathrm{a}$ & $65.5 a$ & $57.7 \mathrm{ab}$ & $51.7 b$ & 0.001 & 9.40 \\
\hline V:C ratio & 4.2 & 4.4 & 4.0 & 4.7 & 0.282 & 15.22 \\
\hline
\end{tabular}

Means in the same row, followed by different lowercase letters, differ $(p<0.05)$ by Tukey's test. CV = coefficient of variation. P-value = significance probability.

In broilers, villus size is not determined only by the rate of cell proliferation, but rather by the relationship between the rates of cell proliferation (in the crypt) and cell death (apoptosis) followed by cell extrusion (at the apex of the villi). For there to be real villus 
growth, the proliferation rate must be higher than extrusion (Boleli \& Morita, 2017). Under normal conditions, the $\mathrm{V}: \mathrm{C}$ ratio should be higher, indicating adequate cell renewal and better nutrient absorption.

At seven days of age, there was a difference $(p<0.05)$ in $\mathrm{VH}, \mathrm{CD}$ and $\mathrm{V}$ : $\mathrm{C}$ ratio in the duodenum, jejunum and ileum between the studied strains (Table 6). The Label Rouge Pescoço Pelado strain showed the highest VH and $\mathrm{V}: \mathrm{C}$ ratios in the duodenum, jejunum and ileum.

Animals that exhibit a good balance between the processes of cell renewal and desquamation of the intestinal mucosa are able to develop well and have better productivity, as they will be able to more effectively absorb the nutrients present in the diet and use them for maintenance and production. However, when we relate the performance results of the Label Rouge Pescoço Pelado strain to the development of the intestinal mucosa, we observe that the strain did not have superior performance results to Carijó, at seven days. As described by Verdal et al. (2010), a greater $\mathrm{VH}$ may be but a physiological attempt to compensate for the low functionality of digestive and enzymatic processes.

\section{Table 6}

Histomorphometric measurements of the small intestine (duodenum, jejunum and ileum) of the Carijó, Carijó Pescoço Pelado (Carijó P), Label Rouge Pescoço Pelado (Label P) and Label Rouge Pesadão (Label) strains at seven days of age

\begin{tabular}{|c|c|c|c|c|c|c|}
\hline \multirow{2}{*}{ Variable } & \multicolumn{6}{|c|}{ Strain } \\
\hline & Carijó & Carijó P & Label P & Label & P-value & CV \% \\
\hline \multicolumn{7}{|c|}{ Duodenum $(\mu \mathrm{m})$} \\
\hline Villus height & $950.8 d$ & $1297.4 \mathrm{c}$ & $1913.2 \mathrm{a}$ & $1595.5 b$ & 0.001 & 11.87 \\
\hline Crypt depth & $188.2 \mathrm{~b}$ & 237.7 a & $201.9 a b$ & $236.0 \mathrm{a}$ & 0.003 & 12.26 \\
\hline $\mathrm{V}: \mathrm{C}$ ratio & $5.2 \mathrm{~b}$ & $5.3 \mathrm{~b}$ & $9.2 \mathrm{a}$ & $6.8 \mathrm{~b}$ & 0.001 & 18.13 \\
\hline \multicolumn{7}{|c|}{ Jejunum $(\mu \mathrm{m})$} \\
\hline Villus height & $1343.3 b$ & $1205.5 b$ & $1592.7 \mathrm{a}$ & $1318.1 \mathrm{~b}$ & 0.001 & 8.23 \\
\hline Crypt depth & $262.3 \mathrm{a}$ & $210.8 b$ & $223.1 \mathrm{~b}$ & $203.7 \mathrm{~b}$ & 0.002 & 12.02 \\
\hline $\mathrm{V}: \mathrm{C}$ ratio & $5.3 c$ & $5.5 \mathrm{bc}$ & $7.3 \mathrm{a}$ & $6.7 a b$ & 0.001 & 14.38 \\
\hline \multicolumn{7}{|c|}{ Ileum $(\mu \mathrm{m})$} \\
\hline Villus height & $875.0 \mathrm{~b}$ & $942.4 a b$ & $1007.7 \mathrm{a}$ & $449.3 \mathrm{c}$ & 0.001 & 8.67 \\
\hline Crypt depth & $140.0 \mathrm{~b}$ & $151.6 \mathrm{ab}$ & 160.7 a & $116.3 \mathrm{c}$ & 0.001 & 10.13 \\
\hline V:C ratio & $5.9 a$ & 5.9 a & $6.2 \mathrm{a}$ & $3.8 \mathrm{~b}$ & 0.001 & 13.70 \\
\hline
\end{tabular}

Means in the same row, followed by different lowercase letters, differ $(p<0.05)$ by Tukey's test. CV = coefficient of variation. P-value $=$ significance probability.

Similar results were observed at 28 days of age (Table 7). There was a difference ( $p$ $<0.05$ ) for $\mathrm{VH}, \mathrm{CD}$ and $\mathrm{V}: \mathrm{C}$ ratio in the duodenum and ileum between all evaluated strains. The Carijó Pescoço Pelado broilers obtained the greatest $\mathrm{VH}$ and $\mathrm{V}: \mathrm{C}$ ratio in the duodenum. $\mathrm{A}$ 
desirable relationship between intestinal villi and crypts occurs when the villi are high and crypts are shallow. Villus height can be reduced, consequently reducing nutrient absorption. This will result in an increased depth of the intestinal crypts, whose purpose is to increase the height of the villi, since regenerative cells, responsible for cell proliferation, are found in these areas (Guerra, 2018).

According to Murakami, Fernandes, Hernandes and Santos (2012), birds with greater intestinal mucosal cell renewal have deeper crypts as a result of high mitotic activity and hyperplasia. Considering that the intestinal mucosa grows continuously due to cell desquamation of the intestinal lumen, cell renewal occurs at the expense of the consumption of nutrients derived from the energy reserves of the bird's body and feed intake.

Greater intestinal development promotes better nutrient utilization, which has a direct impact on performance. However, this was not seen in the present study. In all studied periods, the worst values of performance and relative weight and length of digestive organs were obtained by the Carijó Pescoço Pelado strain. As stated by Verdal et al. (2010) and Santos et al. (2015), birds with inefficient gastric compartments and digestive enzymes have higher villi andhigher $\mathrm{V}: \mathrm{C}$ ratios only in an attempt to compensate for this low functionality, thus improving the absorption processes. Nevertheless, in the current study, this physiological process was not sufficient to improve performance and nutrient utilization in the Carijó Pescoço Pelado strain.

Table 7

Histomorphometric measurements of the small intestine (duodenum, jejunum and ileum) of the Carijó, Carijó Pescoço Pelado (Carijó P), Label Rouge Pescoço Pelado (Label P) and Label Rouge Pesadão (Label) strains at 28 days of age

\begin{tabular}{|c|c|c|c|c|c|c|}
\hline \multirow{2}{*}{ Variable } & \multicolumn{6}{|c|}{ Strain } \\
\hline & Carijó & Carijó P & Label P & Label & P-value & CV \% \\
\hline \multicolumn{7}{|c|}{ Duodenum $(\mu \mathrm{m})$} \\
\hline Villus height & $1385.5 \mathrm{~b}$ & $1553.2 \mathrm{a}$ & $1283.8 \mathrm{bc}$ & $1271.1 \mathrm{c}$ & 0.001 & 5.86 \\
\hline Crypt depth & 543.7 a & $269.1 \mathrm{~b}$ & 277.4 b & $288.3 b$ & 0.001 & 9.03 \\
\hline V:C ratio & $2.5 c$ & $5.5 \mathrm{a}$ & $4.6 \mathrm{ab}$ & $4.4 \mathrm{~b}$ & 0.001 & 14.54 \\
\hline \multicolumn{7}{|c|}{ Jejunum ( $\mu \mathrm{m})$} \\
\hline Villus height & $1106.5 \mathrm{a}$ & 885.5 b & 888.4 b & $967.8 \mathrm{ab}$ & 0.001 & 10.18 \\
\hline Crypt depth & $393.4 \mathrm{a}$ & $358.5 \mathrm{ab}$ & $355.4 \mathrm{ab}$ & $345.1 \mathrm{~b}$ & 0.030 & 7.92 \\
\hline V:C ratio & 2.7 & 2.4 & 2.6 & 2.8 & 0.456 & 15.79 \\
\hline \multicolumn{7}{|c|}{ Ileum ( $\mu \mathrm{m})$} \\
\hline Villus height & $700.3 \mathrm{bc}$ & 772.4 b & 929.0 a & $665.6 \mathrm{c}$ & 0.001 & 7.83 \\
\hline Crypt depth & $194.1 \mathrm{ab}$ & $170.6 \mathrm{~b}$ & 211.8 a & 195.7 a & 0.001 & 8.96 \\
\hline V:C ratio & $3.7 \mathrm{ab}$ & $4.3 \mathrm{a}$ & $4.3 \mathrm{a}$ & $3.2 \mathrm{~b}$ & 0.001 & 12.39 \\
\hline
\end{tabular}

Means in the same row, followed by different lowercase letters, differ $(p<0.05)$ by Tukey's test. CV = coefficient of variation. P-value $=$ significance probability. 
Inadequate nutrition (based on a diet designed for improved commercial strains) for the studied strains; impaired intestinal health; or muscle and adipose tissue deposition different from those of fast-growing commercial strains may explain the performance and nutrient utilization results.

A practice that characterizes the freerange production system is the management of release of the birds in a free area (paddocks). In free areas, birds consume more complex feedstuffs such as grasses, earthworms, insects, seeds, etc. Access to the grazing-free area by birds encourages walking, scratching and moving, in addition to stimulating the consumption of vegetables. Strains that have a more developed digestive tract up to 30 days of age the time when the release management in the free areas begins may be more physiologically prepared for this management.

Therefore, by understanding and comprehending the differences in the growth and development of slow-growing strains used in free-range production systems, one can adopt management practices that better serve the rearing activity, avoiding production losses.

\section{Conclusions}

The Carijó strain has a higher live weight and greater digestive tract development from one to 28 days of age as compared with the Carijó Pescoço Pelado and Label Rouge Pescoço Pelado strains. The best vilus:crypt ratio in the duodenum, jejunum and ileum were observed in the Carijó Pescoço Pelado strain from one to 28 days of age.

\section{References}

Boleli, I. C., \& Morita, V. S. (2017). Mucosa gastrintestinal: crescimento, renovação, reparo e defesa. In: Macari, M., Maiorka, A. Fisiologia das aves comerciais (pp. 205218). Jaboticabal: FUNEP.

Cançado, S. V., \& Baião, N. C. (2002). Efeitos do período de jejum entre o nascimento e o alojamento de pintos de corte e da adição de óleo à ração sobre o desenvolvimento do trato gastrintestinal e concentração de lipase. Arquivo Brasileiro de Medicina VeterináriaeZootecnia, 54(6), 623-629. doi: 10.1590/S0102-09352002000600011

Guerra, R. R. (2018). Morfofisiologia do sistema digestório de não ruminantes. In: N. K. Sakomura, F. G. P Costa, J. B. K. Fernandes, \& L. Hauschild (Eds.), Produção de não ruminantes (pp. 225-246). João Pessoa: Editora UFPB.

Mendonça, M. O., Sakomura, N. K., Santos, F. R., Freitas, E. R., Fernandes, J. B. K., \& Barbosa, N. A. A. (2008). Níveis de energia metabolizável para machos de corte de crescimento lento criados em semiconfinamento. Revista Brasileira de Zootecnia, 37(8), 1433-1440. doi: 10.1590/ S1516-359820080 00800014

Murakami, A. E., Fernandes, J. I. M., Hernandes, L., \& Santos, T. C. (2012). Effects of starter diet supplementation with arginine on broiler production performance and on small intestine morphometry. Pesquisa Veterinária Brasileira, 32(3), 259-266. doi: 10.1590/S0100-736X2012000300014

Oliveira, M. D., Zavarize, K. C., Gomes, N. A., Rocha, F. R. T., Martins, J. M. S., Litz, F. H., \& Castilhano, H. (2012). Aditivos alternativos na alimentação de aves. Pubvet, 6(27), 1425. doi: 10.22256/pubvetv6 n27.1425 
R Core Team (2017). R: A language and environment for statistical computing. Vienna, Austria: RFoundation for Statistical Computing. Retrieved from http://www.Rproject.org/.2017

Reis, T. L., Calixto, L. F. L., Alves, O. S., Lemos, M. J., Lima, M. F., Torres-Cordido, K. A. A., Sousa, F. D. R. (2015). Uso de aditivos nas fases pré-alojamento e pré-inicial sobre o peso corporal e do trato digestório de pintos de corte. Revista Brasileira de Saúde e Produção Animal, 16(4), 811-817. doi: 10. $1590 / S 1519-99402015000400005$

Rocha, P. M. C., Barros, M. E. G., \& Evencio, J., Neto. (2016). Análise morfométrica da parede intestinal e dinâmica de mucinas secretadas no jejuno de frangos suplementados com probiótico Bacillus subtilis cepa C3102. Pesquisa Veterinária Brasileira, 36(4), 312-316. doi: 10.1590/ S0100-736X2016000400010

Rostagno, H. S., Albino, L. F. T., Donzel, J. L., Gomes, P. C., Oliveira, R. F., Lopes, D. C.,... Euclides, R. F. (2011). Tabelas Brasileiras para Aves e Suínos Composição de alimentos e exigências nutricionais. Viçosa, UFV.

Santos, F. R., Stringhini, J. H., Freitas, N. F., Minafra, C. S., Oliveira, P. R., Duarte, E. F., \& Guimarães, G. S. (2015). Aspectos morfológicos e morfométricos do aparelho digestório, perfil bioquímico sérico e atividade de enzimas pancreáticas de frangos de crescimento lento e rápido. Revista Brasileira de Ciências Agrárias, 10(2), 322-327. doi: 10.5039/agraria.v10i 2a4370
Santos, I. I., Corção, G., Kessler, A. M., Laranjeira, V. S., \& Lima, M. S. (2012). Microbiota ileal de frangos de corte submetidos a diferentes dietas. Revista Brasileira de Zootecnia, 41(3), 643-647. doi: 10.1590/ S1516-35982012000300025

Sousa, D. C., Oliveira, N. L. A., Santos, E. T., Guzzi, A., Dourado, L. R. B., \& Ferreira, G. J. B. C. (2015). Caracterização morfológica do trato gastrointestinal de frangos de corte da linhagem Cobb $500^{\circledR}$. Pesquisa Veterinária Brasileira, 35(Suppl. 1), 61-68. doi: 10.1590/S0100736X2015001300011

Uni, Z., Noy, Y., \& Sklan, D. (1999). Posthatch development of small intestine function in the poultry. Poultry Science, 78(1), 215222. doi: 10.1093/ps/78.2.215

Verdal, H., Mignon-Grasteau, S., Jeulin, C., BihanDuval, E., Leconte, M., Mallet, S.,... Narcy, A. (2010). Digestive tract measurements and histological adaptation in broiler lines divergently selected for digestive efficiency. Poultry Science, 89(9), 19551961. doi: $10.3382 / p s .2010-813$

Zocche, A. T., Souza, C. D., \& Gewehr, C. E. (2016). Efeito da idade da matriz e da temperatura de alojamento sobre a absorção do saco vitelino e desempenho zootécnico de frangos de corte. Archives of Veterinary Science, 21(2). doi: 10.5380/ avs.v21i2.44467 